\title{
Levator palpebrae myositis
}

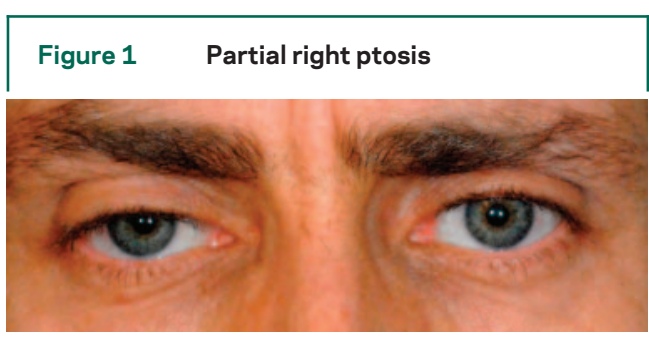

\begin{tabular}{|ll|}
\hline Figure 2 & $\begin{array}{l}\text { Coronal fat-suppressed } \\
\text { gadolinium-enhanced MR scan } \\
\text { of orbits showing discrete } \\
\text { enhancement of the right } \\
\text { levator palpebrae muscle } \\
\text { (arrow) }\end{array}$ \\
\end{tabular}

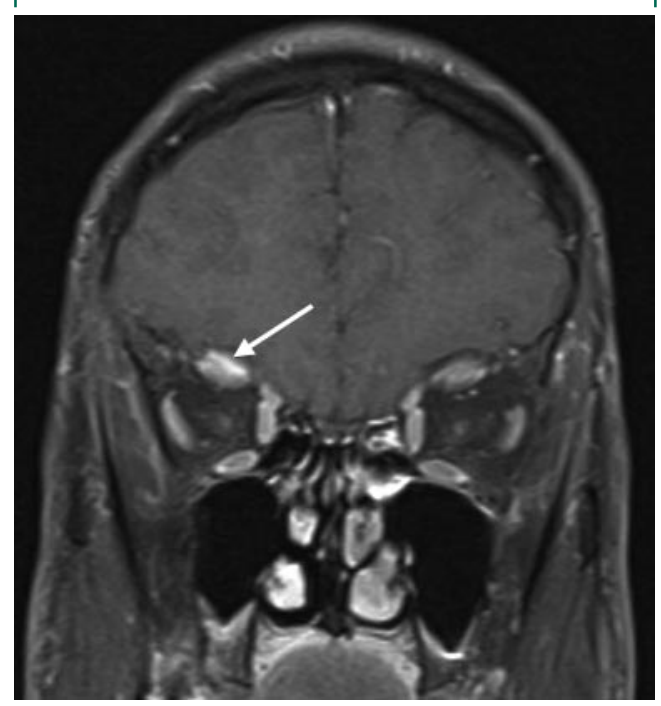

A 45-year-old surgeon presented with a 2-day history of right eye pain and ptosis. Examination showed isolated partial right ptosis (figure 1). MR scan showed discrete enhancement of the right levator palpebrae (figure 2). The pain and ptosis resolved spontaneously over the following week.

Orbital myositis is one of the idiopathic orbital inflammatory syndromes. It presents very rarely as isolated ptosis due to inflammation of the levator palpebrae. ${ }^{1}$ Fat-suppressed, enhanced MR of orbits is the imaging modality of choice. Corticosteroid therapy is usually effective but was not required in our patient nor in a previously reported patient with levator myositis. ${ }^{1}$

Mohammed A. Almekhlafi, MD, William A. Fletcher, MD, FRCPC, Calgary, Alberta, Canada Disclosure: The authors report no disclosures.

Address correspondence and reprint requests to Dr. W.A. Fletcher, Department of Clinical Neurosciences, University of Calgary, Foothills Medical Centre, 1403-29 St N.W., Calgary, AB T2N2T9 Canada; wfletche@ucalgary.ca

1. Wheatcroft S, Elston J. Unilateral ptosis due to isolated involvement of the levator muscle in acute orbital myositis. $\mathrm{Br}$ J Ophthalmol 1999;83:631-632. 


\title{
Neurology
}

\author{
Levator palpebrae myositis \\ Mohammed A. Almekhlafi and William A. Fletcher \\ Neurology 2008;71;1202 \\ DOI 10.1212/01.wnl.0000327565.42954.7a
}

This information is current as of October 6, 2008

\section{Updated Information \& Services}

References

Subspecialty Collections

Permissions \& Licensing

Reprints including high resolution figures, can be found at: http://n.neurology.org/content/71/15/1202.full

This article cites 1 articles, 0 of which you can access for free at: http://n.neurology.org/content/71/15/1202.full\#ref-list-1

This article, along with others on similar topics, appears in the following collection(s):

\section{Eyelids}

http://n.neurology.org/cgi/collection/eyelids

MRI

http://n.neurology.org/cgi/collection/mri

Muscle disease

http://n.neurology.org/cgi/collection/muscle_disease

Information about reproducing this article in parts (figures,tables) or in its entirety can be found online at:

http://www.neurology.org/about/about_the_journal\#permissions

Information about ordering reprints can be found online:

http://n.neurology.org/subscribers/advertise

Neurology ${ }^{\circledR}$ is the official journal of the American Academy of Neurology. Published continuously since 1951, it is now a weekly with 48 issues per year. Copyright . All rights reserved. Print ISSN: 0028-3878. Online ISSN: 1526-632X.

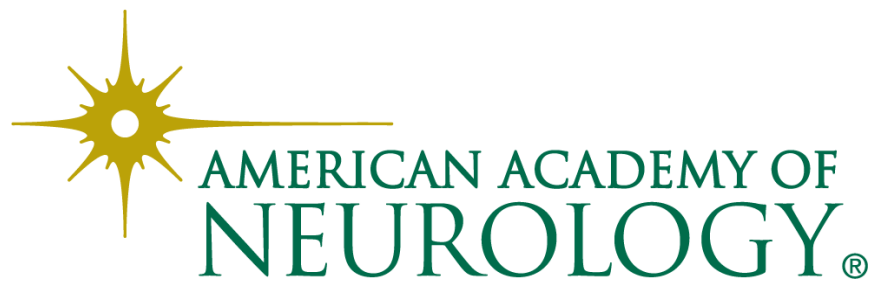

